Journal of Molecular Genetics 3 (1): 8-11, 2011

ISSN: $2070-4267$

(C) Medwell Journals, 2011

\title{
Presence of Type-I Gonadotropin Releasing Hormone Receptor Transcript and Protein in Ovary and Uterus of Goat (Capra hircus)
}

\author{
${ }^{1}$ Atul Upreti, ${ }^{2}$ Anjani Kumar Srivastava, ${ }^{3}$ Vimalkumar Mappilettu Balan and \\ ${ }^{4}$ Kamal Kumar Saxena \\ ${ }^{1}$ Department of Zoology, Radhy Hari Government P.G College, Kahsipur U.K., India \\ ${ }^{2}$ Indian Veterinary Research Institute Izatnagar, Bareilly, U.P., India \\ ${ }^{3}$ S.L.B.P, Thalassery, Kannur Kerela, India \\ ${ }^{4}$ Department of Zoology, Bareilly College, Bareilly, U.P., India
}

\begin{abstract}
Several subtypes of Gonadotropin Releasing Hormone $(\mathrm{GnRH})$ and its receptor are known in non-mammalian vertebrates but the only functional GnRH receptor known in higher mammals so far is type-I GnRH receptor. Though GnRH is primarily known for its role in the regulation of gonadotropins (FSH and LH) secretion from the pituitary, it is also though to be an autocrine/paracrine regulator of ovarian functions. Receptor of gonadotropin releasing hormone is well studied in several animal species but no study has been made to explore the role of $\mathrm{GnRH}$ receptor in extrahypophysial tissues of goat. Here we report, for the first time the confirmation of expression of type-I GnRH receptor in the ovary and uterus of goat. The expression of this receptor in these tissues was confirmed by RT-PCR and western blotting.
\end{abstract}

$\underline{\text { Key words: Gonadotropin releasing hormone, type-I GnRH receptor, goat, mammals, blotting, uterus }}$

\section{INTRODUCTION}

Gonadotropin releasing hormone receptor is a member of Rhodopsin like $\mathrm{G}$ protein coupled receptor super family (Choi et al., 2001; Sealfon et al., 1997). The $\mathrm{GnRH}$ receptor mediates the synthesis and release of FSH and LH in gonadotroph cell population of anterior pituitary. Though GnRH receptor is primarily found in anterior pituitary expression of this receptor is reported in several extrahypophysial tissues and human cell lines like Placenta cell line (Lin et al., 1995), prostate cancer line (Wang et al., 1996), ovary granulose cells (Latouche et al., 1989) and ovarian cancer cell lines (Bramley et al., 1987; Edine et al., 1985; Brus et al., 1997) breast carcinoma and mammary caner cell lines (Cui et al., 2000). Unlike other members of this superfamily, type-I $\mathrm{GnRH}$ receptor lacks the carboxyl terminal tail (Stojilkovic and Catt, 1995) which participates in several downstream reactions through several associated proteins (Bockaert et al., 2003; Emons et al., 1993). Though GnRH receptor and its subtypes are well studied in different animal species no study has been made to explore the role of $\mathrm{GnRH}$ receptor in extrahypophysial tissues of goat. In the present study $\mathrm{GnRH}$ receptor was amplified from goat ovary and uterus using RT-PCR to demonstrate it's transcripts in extrahypophysial tissues. cDNA was synthesized from
RNA isolated from ovary and uterus of goat. A $408 \mathrm{bp}$ fragment corresponding to the position $81-488$ of $987 \mathrm{bp}$ open reading frame of the GnRH-R (coding amino acids 146-266) was amplified form goat ovary and uterus cDNA using specific primers designed to characterize this receptor from goat pituitary previously (Upreti et al., 2010). The expression of functional $\mathrm{GnRH}$ receptor protein in ovary and uterus of goat was further confirmed by western blotting. The membrane protein was isolated from ovary and uterus of goat and western blotting was performed using monoclonal antiserum raised in mouse against human $\mathrm{GnRH}$ receptor as primary antibody.

\section{MATERIALS AND METHODS}

RNA isolation and cDNA synthesis: Tissue samples were collected from local abattoir, immediately after slaughter in RNAlater solution (Qiagen, Germany). The total RNA from the ovary and uterus of goat was isolated using RNAeasy Kit (Qiagen) following the manufacturers protocol. The purity and integrity of RNA was confirmed by spectrophotometry and gel electrophoresis. The cDNA was synthesized from the RNA using MuMLV reverse transcriptase (MBI-Fermentas) and oligo-dT primers (MBI-Fermentas). For cDNA synthesis $20 \mu \mathrm{L}$ reaction volume was prepared containing $5 \mu \mathrm{g}$ of total RNA, $5 \mu \mathrm{g}$ of oligo dT primer, $1 \mathrm{mM}$ dNTP mix, $20 \mathrm{U}$ of ribonuclease

Corresponding Author: Atul Upreti, Department of Zoology, Radhy Hari Government P.G College, Kahsipur U.K., India 
inhibitor and $20 \mathrm{U}$ of MuMLV reverse transcriptase. The temperature conditions were followed as mentioned in manufacturer's protocol.

PCR Amplification of type-I GnRH-R: A 408 bp fragment corresponding to the position $81-488$ of $987 \mathrm{bp}$ open reading frame of the GnRH-R (coding amino acids 146-266) was amplified form goat ovary and uterus cDNA using specific primers (forward 5'-GCCAAGCCAA-TCATGA ACTGTCC-3' and reverse 5'GCCAAGCCAATCATGA ACTGTCC3'). Polymerase Chain Reaction (PCR) was carried out in $25 \mu \mathrm{L}$ reaction volume containing $\sim 70 \mathrm{ng}$ of cDNA, $20 \mathrm{pM}$ of each primer, $400 \mu \mathrm{M}$ of dNTP mix, 2.5 unit of Taq DNA polymerase and $1.5 \mathrm{mM} \mathrm{MgCl}_{2}$ using $\mathrm{T}$ Personal Thermocycler. The PCR programme used to amplify 408 bp product involved initial denaturation at $95^{\circ} \mathrm{C}$ for $3 \mathrm{~min}, 32$ cycles of denaturation at $95^{\circ} \mathrm{C}$ for $1 \mathrm{~min}$, annealing at $50^{\circ} \mathrm{C}$ for $30 \mathrm{sec}$ and extension at $72^{\circ} \mathrm{C}$ for $1 \mathrm{~min}$ followed by a final extension of $10 \mathrm{~min}$ at $72^{\circ} \mathrm{C}$. The amplified PCR products were electrophorezised with 100 bp DNA ladder (MBI Fermentas) on ethidium bromide stained $1 \%$ agarose gel and were visualized under UV and photographed.

Protein isolation and western blotting: Membrane fraction of the protein was extracted from ovary and uterus of goat using method described by Karande et al. (1995). The 10\% homogenate of tissue was prepared in extraction buffer (20 mM Tris- $\mathrm{HCl} \mathrm{pH} 8.0,10 \mathrm{mM} \mathrm{NaCl}$, $1 \mathrm{mM} \mathrm{CaCl}$ and $1 \mathrm{mM}$ PMSF). The homogenate was centrifuged at $800 \mathrm{~g}$ for $10 \mathrm{~min}$ to pellet down the cell debries, the centrifugation was repeated for 4 times. The resultant supernatant was centrifuged at $10,000 \mathrm{~g}$ for $30 \mathrm{~min}$ at $4^{\circ} \mathrm{C}$ the supernatant was discarded and the pellet was solubilized in CHAPS buffer ( $5 \mathrm{mM}$ CHAPS in $10 \mathrm{mM}$ Tris- $\mathrm{HCl} \mathrm{pH}$ 7.4). Protein samples were electrophorized in $10 \%$ SDS polyacrylamide gel using standard protocol (Sambrook et al., 2001). The protein was transferred to the membrane by electro-blotting method using standard protocol (Sambrook et al., 2001). The membrane was blocked with $3 \%$ bovine serum albumin solution in wash buffer ( $50 \mathrm{mM}$ Tris- $\mathrm{HCl} \mathrm{pH} 7.5,200 \mathrm{mM} \mathrm{NaCl}$ and $0.05 \%$ Tween 20) and then incubated in wash buffer containing F1G4 anti human GnRH-R mouse monoclonal antibody (courtesy Dr. A. Karanade I.I.Sc Bangalore India) followed by washing with wash buffer for several times. The membrane was then incubated in secondary antibody (IgG goat anti mouse AP conjugated, Bangalore Genei) and again washed with wash buffer for several times. The colour was developed with BCIP/NBT substrate solution (Ambion).

\section{RESULTS AND DISCUSSION}

RNA isolation, cDNA synthesis and PCR amplification: The RNA yield using RNeasy Mini Kit was found about $1.5 \mu \mathrm{g} \mathrm{mg}^{-1}$ of tissue and A260/280 of the RNA sample obtained was 1.88 indicating the high purity of the RNA samples. PCR with specific primer pair using cDNA from ovary and uterus RNA gave products of expected size (408 bp) confirming the presence of type I GnRH receptor transcript in ovary and uterus (Fig. 1).

Western blotting: The western blot analysis showed band corresponding $\sim 62 \mathrm{KD}$ in both ovary and uterus samples (Fig. 2).

Though GnRH is primarily known for its role in the regulation of gonadotropin secretion from the pituitary, the presence of $\mathrm{GnRH}$ and its receptor in the granulosa-luteal cells and ovarian surgace epithelial cells suggests that $\mathrm{GnRH}$ exerts its action in an autocrine/paracrine manner to modulate both basal and gonadotropin stimulated steiroidogenesis, folliculogenesis and luteolysis (Leung and Steele, 1992). Many workers believe that the presence of GnRH and it's receptor in addition to regulating gonadotropins and identification of structural variants of $\mathrm{GnRH}$ in extrahypothalamic and detailed molecular delineation of the interaction of these extrahypophysial tissues indicates

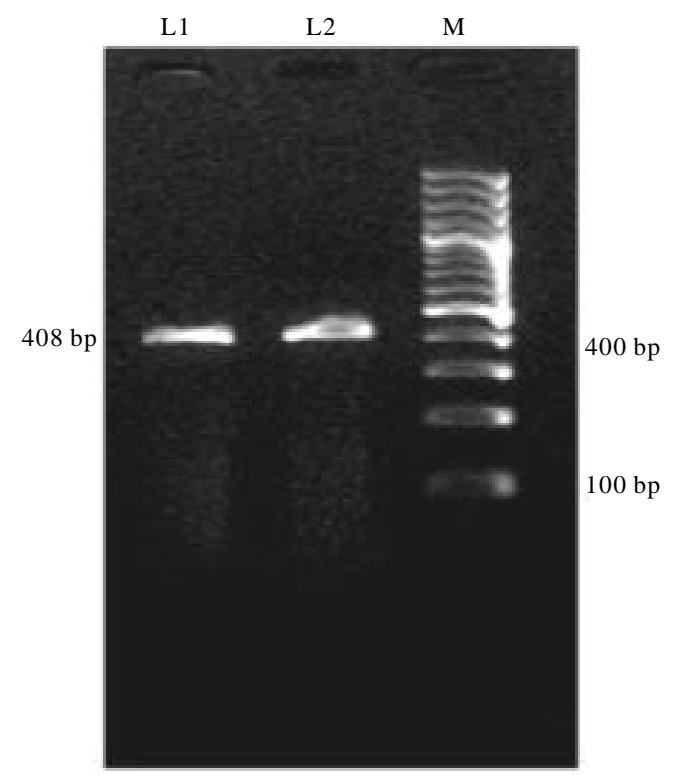

Fig. 1: 408 bp PCR product from ovary and uterus of goat Lane M; molecular size marker, Lane1; 408 bp product from ovary, Lane 2; 408 bp PCR product from uterus 


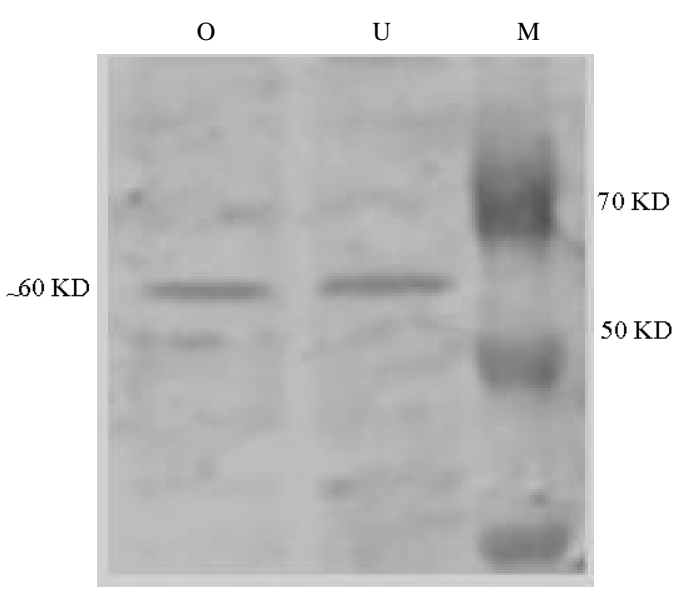

Fig. 2: Western blot of protein samples, O: Ovary, U: Uterus and M: Marker

that these molecules have been co-opted during evolution for other functions $\mathrm{GnRHs}$ with the type I GnRH receptor and the selective activation of intracellular signals will contribute to the development of novel $\mathrm{GnRH}$ therapeutics (Millar et al., 2004). Although, the presence of GnRH-R in the extrahypophysial tissues from various species have been suggested by studies using RT-PCR, the current findings represents the first report of the GnRH-R transcript and functional protein in extrahypophysial tissue sites of goat. In the present study the presence of GnRH-R in the ovary and uterus of goat was demonstrated by RT-PCR and western blotting. The $408 \mathrm{bp}$ products of type I GnRH-R were amplified from cDNA prepared from total mRNA isolated from ovary and uterus of goat confirming the presence of type I GnRH receptor transcript in these tissues. The western blot analysis was performed to confirm the expression of functional protein in the ovary and uterus of goat. The extracted protein was analyzed by SDS-PAGE. Western blot revealed the band of $62 \mathrm{KD}$ size representing the $\mathrm{GnRH}$ receptor protein both the samples. This finding is in accordance to other reports about the expression of $\mathrm{GnRH}$ receptor in extrahypophysial tissues suggesting it's possible role in autocrine or paracrine regulation of reproductive processes beside the central hormonal axis (Sengupta and Sridaran, 2008). As expression of GnRH-I and GnRH-II mRNAs identical to their brain counter parts have been demonstrated in various ovarian tissues including Ganulosa-Luteal (GL) cells and the Ovarian Surface Epithelial (OSE) cells (Bourne et al., 1980; Grundker et al., 2002; Kang et al., 2000) the findings provide strong evidence that ovary and uterus are possible target organs for autocrin/paracrine functions of $\mathrm{GnRH}$. Further research like studying the various levels of GnRHs and type-I GnRH receptor through out the ovarian cycle using quantitative PCR will explore the functional aspect of this receptor in these tissues which may help in understanding the possible action of $\mathrm{GnRH}$ analogs in extrahypophysial tissues of goat in addition to their effects on pituitary function.

\section{CONCLUSION}

The present study confirms the expression of type-I gonadotropin releasing hormone receptor in extrahypophysial tissues (ovary and uterus) of goat. This provides strong evidence that these tissues are target organs for gonadoreopin releasing hormone and this hormone has autocrine/paracrine functions which must be studied further to better understand the molecular mechanism of this hormone function.

\section{ACKNOWLEDGEMENT}

The researchers are thankful to Director, Indian Veterinary Research Institute Izatnagar Uttar Pradesh India for providing necessary research facilities.

\section{REFERENCES}

Bockaert, J., P. Marin, A. Dunuis and L. Fagni, 2003. The magic tail of $G$ protein-coupled receptors: An anchorage for functional protein networks. FEBS Lett., 546: 65-72.

Bourne, G., S. Regiani, A. Payne and J. Marshall, 1980. Testicular GnRH receptor: Characterization and localization on intestinal cells. J. Clin. Endocrinol. Metab., 51: 407-409.

Bramley, T.A., D. Stirling, I.A. Swanston, G..S. Menzies, A.S. McNeilly and D.T. Baird, 1987. Specific binding sites for gonadotropin-releasing hormone, LH/chorionic gonadotropin, low-density lipoprotein, prolactin and FSH in homogenates of human corpus luteum. II. Concentrations throughout the luteal phase of the menstrual cycle and early pregnancy. J. Endocrinol., 113: 317-327.

Brus, L., C.B. Lambal, J. de koning, M.N. Helder, N.M. Janssens and J. Schoemaker, 1997. Specific gonadotropin releasing hormone analogues binding predominantly in human luteinized follicular aspirates and not in human pre-ovulatory follicles. Human Reproduct., 12: 767-773.

Choi, K.C., N. Auersperg and P.C. Leung, 2001. Expression and antiproliferative effect of a second form of gonadotropin-releasing hormone in normal and neoplastic ovarian surface epithelial cells. J. Clin. Endocrinol. Metab., 86: 5075-5078. 
Cui, J., R.G. Smith, G.R. Mount, J.L. Lo and J. Yu et al., 2000. Identification of phe 313 of the gonadotropin releasing hormone $\mathrm{GnRH}$ receptor as a site critical for the binding of nonpeptide gnrh antagonists. Mol. Endocrinol., 14: 671-681.

Edine, K.A., C.A. Flanagan and R.P. Millar, 1985. GnRH binding sites in human breast carcinoma. Science, 229: 989-989.

Emons, G., O. Ottmann, M. Becker, G. Irmer and B. Springer et al., 1993. High affinity binding and direct antiproliferative effects of LHRH analogues in human ovarian cancer cell lines. Cancer Res., 54: 5439-5446.

Grundker, C., A.R. Gunthert, S. Westphalen and G. Emons, 2002. Biology of the gonadotropin-releasing hormone system in gynecological cancers. Eur. J. Endocrinol., 146: 1-14.

Kang, S.K., K.C. Choi, K.W. Cheng, P.S. Nathwani, N. Auersperg and P.C. Leung, 2000. Role of gonadotropin-releasing hormone as an autocrine growth factor in human ovarian surface epithelium. Endocrinol., 141: 72-80.

Karande, A., K. Rajeswary, D.J. School and J.H.M. Hilgers, 1995. Establishment of immunological probes to study human GnRH-R. Mol. Cell. Endocrinol., 114: 52-56.

Latouche, J., M. Crumeyrolle-Arias and D. Jordan, 1989. GnRH receptors in human granulosa cells: Anatomical localization and characterization by autoradiographic study. Endocrinology, 125: 1739-1741.

Leung, P.C.K. and G.L. Steele, 1992. Intracellular signaling in the gonads. Endocrin. Rev., 13: $476-498$.
Lin, L.S., V.J. Roberts and S.S. Yen, 1995. Expression of human gonadotropin- releasing hormone receptor gene in the placenta and its functional relationship to human chorionic gonadotropin secretion. J. Clin. Endocrinol. Metab., 80: 580-585.

Millar, R.D.B., Z. Lu, A.J. Pawson, C.A. Flanagan, K. Morgan and S.R. Maudsley, 2004. Gonadotropinreleasing hormone receptors. Endocrine Rev., 252: $235-275$.

Sambrook, J., E.F. Fritsch and T. Maniatis, 2001. Molecular Cloning: A Laboratory Manual. 3rd Edn., Cold Spring Harbor Laboratory Press, New York.

Sealfon, S.C., H. Weinstein and R.P. Millar, 1997. Molecular mechanisms of ligand interaction with the GnRH-R. Endocr. Rev., 182: 180-205.

Sengupta, A. and R. Sridaran, 2008. Expression and localization of gonadotropin-releasing hormone receptor in the rat oviduct during pregnancy. $\mathrm{J}$. Histochem. Cytochem., 261: 25-31.

Stojilkovic, S.S. and K.J. Catt, 1995. Novel aspects of GnRH-induced intracellular signaling and secretion in pituitary gonadotropes. J. Neuroendocrinol., 7: 739-757.

Upreti, A., V.M. Balan, A.K. Srivastava nd K.K. Sexena, 2010. Characterization of gene encoding type-I gonadotropin releasing hormone receptor of goat capra hircus. IJB, 21: 62-70.

Wang, Q.F., K.I. Tilly, J.L. Tilly, F. Preffer, A.L. Schneyer, W.F. Crowley and P.M. Sluss, 1996. Activin inhibits basal and androgen-stimulated proliferation and induces apoptosis in the human prostatic cancer cell line, LNCaP. Endocrinology, 137: $5476-5483$. 